\title{
Interleukin-27 Subunit Beta
}

National Cancer Institute

\section{Source}

National Cancer Institute. Interleukin-27 Subunit Beta. NCI Thesaurus. Code C117090.

Interleukin-27 subunit beta (229 aa, $25 \mathrm{kDa}$ ) is encoded by the human EBI3 gene. This protein plays a role in the regulation of cytokine expression, the modulation of inflammation and the stimulation of innate immunity. 